\title{
IMPLEMENTASI KOMPETENSI SIKAP SPIRITUAL KURIKULUM 2013 PADA PROSES PEMBELAJARAN PENDIDIKAN AGAMA ISLAM JENJANG SEKOLAH MENENGAH ATAS (SMA)
}

\author{
Farhan Sifa Nugraha ${ }^{1}$, Dahwadin $^{2}$ \\ ${ }^{1}$ Sekolah Menengah Atas Negeri 2 Cimalaka \\ ${ }^{2}$ Sekolah Tinggi Agama Islam (STAI) Al Musaddadiyah Garut, Jawa Barat, Indonesia \\ Jln. Mayor Syamsu No. 02, Jayaraga, Kec. Tarogong Kidul, Kabupaten Garut, Jawa Barat 44151 \\ Email: ${ }^{1}$ farhansifanugraha@gmail.com, ${ }^{2}$ dahwadin@gmail.com \\ DOI: $10.29313 /$ tjpi.v8i1.4865 \\ Accepted: Agust 7th, 2019. Approved: October 11th, 2019. Published: Oktober 14th, 2019
}

\begin{abstract}
The spiritual attitude competence, which is developed and applied on the subject of Islamic Education, has great influences on the changes and developments of spiritual attitudes among students, the attitudes expected likely to happen after they learn the material subjects, taught by their teacher, with various components stated in the content standard of Curriculum 2013. The components are: 1) integration in the instructional activity, 2) prayer before and after the instructional activity in the classroom, 3) good manners in the speaking behaving, 4) wearing heat and respectful dress, 5) greeting when entering the classroom, 6) implementing the service of the religion, 7) thank god for comforts acquired, 8) respecting differences, 9) helpfulness among peers and 10) standing in line when using school facilities.
\end{abstract}

Keywords: Spiritual Attitude Competencies; 2013 Curriculum.

\begin{abstract}
Abstrak
Kompetensi sikap spiritual yang dikembangkan dan diterapkan pada mata pelajaran Pendidikan Agama Islam memiliki pengaruh yang sangat besar terhadap perubahan dan peningkatan tingkah laku di kalangan peserta didik. Tingkah laku yang diharapkan tersebut memungkinkan terjadi setelah mereka mempelajari bahan ajar yang disampaikan oleh guru yang bersangkutan dengan berbagai komponen yang tercantum dalam Standar Isi Kurikulum 2013. Komponen-komponen tersebut diantaranya: 1) integrasi dalam kegiatan pembelajaran, 2) berdoa saat memulai dan mengakbiri kegiatan, 3) santun dalam berbicara dan berperilaku, 4) berpakaian yang rapi dan sopan, 5) mengucapkan salam saat masuk ke dalam kelas, 6) melaksanakan ibadah, 7) mensyukuri nikmat yang diperoleh, 8) menghormati perbedaan, 9) sikap saling menolong diantara sesama dan 10) antri saat memakai fasilitas sekolah ataupun madrasah.
\end{abstract}

Kata Kunci: Kompetensi Sikap Spiritual; Kurikulum 2013. 


\section{PENDAHULUAN}

Dalam lingkup pendidikan, khususnya yang terdapat pada mata pelajaran Pendidikan Agama Islam, proses pembelajaran dapat diartikan sebagai upaya dalam membentuk sikap diantaranya sikap spiritual atau kita sebut sebagai sikap keberagamaan untuk diperhatikan oleh guru yang bersangkutan. Pada prosesnya pembelajaran Pendidikan Agama Islam merupakan upaya sadar dan terencana dalam menyiapkan siswa untuk mengenal, memahami, menghayati, mengimani, bertakwa serta berakhlak mulia dalam mengamalkan ajaran agama Islam dari sumber utamanya kitab suci Al-Quran dan Hadits melalui kegiatan bimbingan, pengajaran, latihan, serta penggunaan pengalaman. Disertai dengan tuntutan untuk menghormati penganut agama lain, hubungannya dengan kerukunan antar umat beragama di dalam masyarakat hingga terwujud kesatuan dan persatuan bangsa.

Oleh karena itu ketika kita menyebut pendidikan Islam, maka akan mencakup dua hal, 1) mendidik siswa untuk berperilaku sesuai dengan nilai-nilai atau akhlak Islam, 2) mendidik para siswa untuk mempelajari materi ajaran Islam. Tayar Yusuf (Abdul Majid, 2012 : 11). mengemukakan bahwa proses pembelajaran Pendidikan Agama Islam ini sebagai usaha sadar generasi tua untuk dapat mengalihkan pengalamannya berupa pengetahuan, kecakapan, dan keterampilan pada generasi muda agar kelak menjadi generasi muslim yang bertakwa kepada Allah SWT, berbudi pekerti luhur, dan berkepribadian yang dapat memahami, menghayati, serta mengamalkan ajaran agama Islam dalam kehidupan sehari-hari.

Di samping argumentasi yang telah dikemukakan terkait dengan proses pembelajaran tersebut, perlu kita ketahui banyaknya anggapan yang muncul dan kurang menyenangkan terhadap pendidikan agama, seperti Islam diajarkan lebih pada hafalan padahal Islam penuh dengan nilainilai yang harus dipraktekkan.(Abdul Majid,
2012 : 12). Inilah yang menyebabkan bahwa mata pelajaran tersebut di lingkungan sekolah dan madrasah harus diintegrasikan antara kompetensi kognitif (KI-3), psikomotor (KI-4), dengan kompetensi sikap spiritual (KI-1) dalam konteks Kurikulum 2013.

Untuk mencapai kompetensi sikap spiritual tersebut pada Kurukulum 2013 harus ada usaha yang sangat kuat dan sungguh-sungguh dari seorang guru yang ingin mencerdaskan bangsa dan mengubah generasi penerus menjadi generasi yang cerdas, beriman, dan bertakwa. Cerdas dalam arti memiliki kecakapan dalam menghadapi tantangan kehidupan pada masa depan dan mampu memberdayakan sumber daya alam dan sumber daya manusia sebagai jaminan kesejahteraan dan kemakmuran bangsa dan negara (Hasan Basri, 2009 : 135).

Pembelajaran dalam konteks Kurikulum 2013 dapat diorientasikan untuk menghasilkan insan Indonesia yang produktif, kreatif, inovatif melalui penguatan sikap, keterampilan, dan pengetahuan yang terintegrasi.(Yunus Abidin, 2014 : 17). Kompetensi sikap dalam mata pelajaran ini, dapat dilihat melalui aktivitas pengamalan ajaran Islam setelah menerima, mempraktekkan dan menghayati bahan ajar yang dipelajari melalui kompetensi kognitif (KI-3) dan psikomotor (KI-4). Kompetensi Kurikulum 2013 dinyatakan dalam bentuk kompetensi inti kelas yang dapat dirinci lebih lanjut terhadap kompetensi dasar pada mata pelajaran yang bersangkutan. Kompetensi inti menjadi unsur pengorganisasian kompetensi dasar, semua kompetensi dasar pada proses pembelajaran dapat dikembangkan untuk mencapai kompetensi inti tersebut (Yunus Abidin, 2014 : 21). 


\section{PEMBAHASAN}

\section{PERENCANAAN PEMBELAJARAN KOMPETENSI SIKAP SPIRITUAL KURIKULUM 2013}

Setiap kegiatan yang mempunyai arah dan tujuan memerlukan suatu perencanaan yang tepat. Tanpa didahului dengan perencanaan yang tepat, tujuan kegiatan tidak akan tercapai secara efisien dan efektif. Tanpa perencanaan jalannya suatu usaha akan bersifat untung-untungan. Keputusan-keputusan yang diambil hanya merupakan pilihan-pilihan sesaat yang sempit. Pembangunan dalam bidang pendidikan memerlukan adanya proses pengaturan dan perencanaan secermat mungkin, komprehensif, akurat, dan efisien serta berdasarkan perhitungan yang matang, karena tanpa perencanaan yang sistematik dan rasional upaya pembangunan tidak akan dapat dilaksanakan dengan efektif. Dengan perencanaan usaha yang terpadu, terkoordinasi, pemanfaatan sumber daya, urutan prioritas, kurun waktu yang dihendaki, distribusi wewenang, dan tanggung jawab dapat disusun dan dihitung terlebih dahulu secara sistematis, cermat, dan komprehensif (Afifuddin, 2004 : 42).

Perencanaan yang dimaksud untuk mengembangkan proses pembelajaran Pendidikan Agama Islam pada kompetensi sikap spiritual dengan tujuan menciptakan karakteristik siswa di sekolah menjadi manusia yang seutuhnya. Yaitu manusia yang lengkap, selaras, serasi dan seimbang dari semua segi kepribadiannya, sehingga manusia seutuhnya itu adalah personal atau individu-individu yang mampu menjangkau segenap hubungan dengan Tuhan, dengan lingkungan, dengan manusia lain dalam suatu kehidupan sosial yang konstruktif dan dengan dirinya sendiri. Personal atau individu yang demikian pada dirinya terdapat suatu kepribadian terpadu, baik dari unsur akal pikiran, perasaan, moral dan keterampilan (cipta, rasa dan karsa) jasmani maupun rohani yang dapat berkembang secara penuh. Integrasi perkembangan dari unsur-unsur itulah yang akan mewujudkan manusia utuh sebagai tujuan pendidikan bangsa Indonesia (Sardiman A.N, 2011 : 118).

Untuk mewujudkan tujuan pendidikan dalam bidang kompetensi sikap spiritual, maka perlu adanya pengembangan mengenai administrasi pembelajaran. Administrasi pembelajaran tersebut dikembangkan sebagai langkah dari suatu perencanaan dan pedoman dalam kegiatan pembelajaran. Administrasi pembelajaran disusun melalui Rencana Pelaksanaan Pembelajaran (RPP), Program Kompetensi, Evaluasi Kompetensi Sikap Spiritual, Program Tahunan, Program Semester, Format Penilaian Sikap, Format Penilaian Diri dan Format Penilaian Antar Teman. Administrasi tersebut, disusun untuk dilaksanakan pada waktu kegiatan pembelajaran di dalam kelas maupun di luar kelas, dengan tujuan semua siswa dapat mengimplementasikan sikap spiritual ke dalam kehidupan sehari-hari.

Perlu kita ketahui bahwa di dalam merumuskan tujuan sebagai rancangan dari perencanaan administrasi pembelajaran yang dimaksud, harus dihubungkan dengan keadaan atau karakteristik siswa, sehingga proses kegiatan pembelajaran dapat berjalan dengan efektif. Ada tiga hal yang perlu diperhatikan dalam memahami karakteristik siswa diantaranya: 1) Karakteristik atau keadaan yang berkenaan dengan kemampuan awal, seperti, kemampuan intelektual, berpikir, mengucapkan hal-hal yang berkaitan dengan aspek psikomotor dan lain-lain. 2) Karakteristik yang berhubungan dengan latar belakang dan status sosial. 3) Karakteristik yang berkenaan dengan perbedaan-perbedaan kepribadian, seperti sikap, perasaan, minat dan lain-lain.

Pengetahuan mengenai karakteristik siswa ini memiliki arti yang cukup penting terhadap perencanaan pembelajaran, terutama bagi guru. Informasi mengenai karakteristik siswa akan berguna dalam memilih dan menentukan pola pembelajaran 
yang lebih baik yaitu yang dapat menjamin kemudahan belajar bagi siswa. Sehingga guru akan mudah dalam merekonstruksi dan mengorganisasikan materi pelajaran sedemikan rupa yang berkaitan dengan kompetensi sikap spiritual pada mata pelajaran Pendidikan Agama Islam.

Hal tersebut akan membuat guru untuk bisa berkreatif dalam menciptakan kegiatan pembelajaran yang bervariasi agar setiap individu siswa tidak merasa kecewa. Selain itu sangat bermanfaat bagi guru dalam memotivasi dan membimbing siswa dalam proses pembelajarannya. (Sardiman A.N, $2011: 120-121)$.

\section{PEMBELAJARAN KOMPETENSI SIKAP SPIRITUAL KURIKULUM 2013}

Pendidikan Agama Islam di samping mengingternalisasikan nilai-nilai Islami, juga mengembangkan siswa agar mampu melakukan pengamalan nilai-nilai itu secara dinamis dan fleksibel dalam batas-batas konfigurasi idealitas wahyu Tuhan. Hal ini berarti Pendidikan Agama Islam secara optimal harus mampu mendidik siswa agar memiliki kedewasaan atau kematangan dalam beriman, bertakwa, dan mengamalkan hasil pendidikan yang diperoleh sehingga menjadi para pemikir sekaligus pengamal ajaran Islam yang dialogis terhadap perkembangan kemajuan zaman. Dengan kata lain, harus mampu menciptakan para mujtahid baru dalam bidang kehidupan duniawi dan ukhrawi yang berkesinambunmgan secara interaktif tanpa mengkotakan antara kedua bidang itu.

Duniawi bagi agama Islam mengandung nilai ukhrawi karena dengan amal baik di dunia manusia akan mampu meraih kebahagiaan di akhirat. Sedang ukhrawi adalah tujuan akhir dari kehidupan manusia muslim. Tujuan akhir inilah yang dapat menjiwai atau mewarnai amal perilakunya di dunia yang tak terpisahkan dari tuntutan nilai nilai keukhrawiannya. (Muzayyin Arifin, 2012 : 111). Untuk mewujudkan nilai-nilai keukhrawiannya sebagai bentuk kristalisasi nilai-nilai tujuan akhir harus meliputi semua aspek yang terintegrasi dalam pola kepribadian ideal yang bulat dan utuh. Pola kepribadian ideal yang bulat dan utuh adalah suatu kerangka dasar psikologis yang memberi bentuk dan corak dasar perilaku rohaniah manusia yang menggejala dalam perilaku lahiriah secara bulat sebagai refleksi dari nilai-nilai yang mempribadi dalam dirinya. (Muzayyin Arifin, 2012: 114).

Untuk mewujudkan nilai-nilai tersebut, maka perlu dikembangkan suatu kompetensi yang ada pada mata pelajaran Pendidikan Agama Islam di lingkungan sekolah, diantaranya mengenai kompetensi sikap spiritual. Kompetensi sikap spiritual yaitu karakter dan sikap yang merupakan bagian dari kesadaran yang paling dalam pada seseorang yang berhubungan dengan yang tidak hanya mengakui keberadaan nilai tetapi juga kreatif untuk menemukan nilainilai yang baru. Menurut Willy Susilo, sikap spiritual adalah kemampuan untuk mencari dan menemukan makna tertinggi dengan bantuan kecerdasan intelektual dan emosional serta kemampuan untuk memahami sistem nilai yang berlaku pada orang atau sekelompok orang.

Menurut Zohar and Marshall, ada sembilan ciri pengembangan kompetensi sikap spiritual yang tinggi untuk diimplementasikan, diantaranya:

1. Kemampuan bersikap fleksibel atau adaptif.

2. Tingkat kesadaran diri yang tinggi.

3. Kemampuan untuk menghadapi dan mengatasi penderitaan.

4. Kemampuan untuk menghadapi dan melampaui rasa sakit.

5. Kualitas hidup yang dillhami oleh visi dan nilai keengganan untuk membuat kerugian yang tidak perlu.

6. Kecenderungan untuk melihat segala sesuatu secara kholistik.

7. Kecenderungan untuk selalu bertanya mengapa.

8. Memiliki kemudahan untuk melawan konvensi. 
Sementara itu, menurut Ary Ginanjar Agustian, ada delapan internalisasi karakter sikap spiritual, yaitu:

1. Berbakti dan memberi.

2. Jujur dan terpercaya.

3. Adil.

4. Kerjasama dan bersatu.

5. Berjuang dan bersikap teguh.

6. Ramah dan penyayang.

7. Bersyukur dan berterima kasih.

8. Bertanggung jawab, pemaaf dan pengasih.

Semua itu nantinya akan menghasilkan paham dari sikap spiritual, seperti integritas atau kejujuran, energi atau semangat, inspirasi atau inisiatif, bijaksana, dan keberanian dalam pengambilan keputusan, (Uhar Suharsaputra, 2010 : 205) terlebih dengan diimplementasikannya pembelajaran kompetensi sikap spiritual pada mata pelajaran Pendidikan Agama Islam yaitu dapat membentuk masyarakat muslim yang moderat. Karena Indonesia adalah ragam yang sangat besar dimana memiliki banyak perbedaan agama, budaya, suku, dan bangsa. Perbedaan ini menghendaki seorang muslim menurut nilainilai agama Islam yang diajarkan, diantaranya adanya rasa toleransi yang sangat tinggi dan tidak ada perselisihan. (Hasbiyallah, 2017 : 49).

\section{EVALUASI PEMBELAJARAN KOMPETENSI SIKAP SPIRITUAL KURIKULUM 2013}

\footnotetext{
Evaluasi dapat diartikan sebagai proses pengumpulan informasi untuk mengetahui efektivitas (keterlaksanaan dan ketercapaiannya) kegiatan-kegiatan yang telah dilaksanakan dalam upaya mengambil keputusan. Evaluasi juga dapat diartikan sebagai usaha untuk mendapatkan informasi secara berkala, berkesinambungan, dan menyeluruh tentang proses dan hasil dari perkembangan sikap dan perilaku atau tugastugas perkembangan para siswa melalui program kegiatan yang telah dilaksanakan.
}

Sementara itu penilaian kegiatan dalam pembelajaran yang merupakan bagian dari proses evaluasi kegiatan di lingkungan sekolah adalah segala upaya, tindakan, atau proses untuk menentukan derajat kualitas kemajuan yang berkaitan dengan pelaksanaan sebuah program yang dilaksanakan dengan mengacu pada kriteria atau patokan-patokan tertentu sesuai dengan program yang dilaksanakan. Kriteria atau patokan yang dipakai untuk menilai tingkat keberhasilan pelaksanaan pembelajaran kompetensi sikap spiritual di lingkungan sekolah mengacu pada implementasi yang dilaksanakan oleh para siswa atas bimbingan dari guru mata pelajaran Pendidikan Agama Islam yang dapat berperan membantu siswa dalam memperoleh perubahan perilaku dan pribadi ke arah yang lebih baik. (Anas Salahudin, $2010: 218$ )

Proses evaluasi dan penilaian dalam pembelajaran kompetensi sikap spiritual (KI-1) para siswa pada mata pelajaran tersebut dilakukan dengan cara yang berbeda jika dibandingkan dengan evaluasi terhadap kompetensi kognitif (KI-3) dan psikomotorik (KI-4). Pada pelaksanaannya dapat dilakukan dengan menggunakan penilaian non tes terhadap kompetensi sikap spiritual. Guru mata pelajaran yang bersangkutan di lingkungan sekolah harus menilai beberapa objek yang berkaitan dengan pembelajarannya. Misalnya, sikap terhadap materi pelajaran, sikap terhadap tema-tema yang diintegrasikan, sikap terhadap tautan praktik, sikap terhadap guru, sikap terhadap semua proses pembelajaran, sikap para siswa yang berkaitan dengan nilai dan norma. (Ibnu Hajar, 2013 : 277-278).

Konsekuensinya, bahwa proses evaluasi baru dapat dilakukan jika program pembelajarannya sudah berjalan dalam satu periode, sesuai dengan tahapan dan sasaran yang dirancang. Misalnya untuk satu tahun pelajaran. Dapat juga untuk satu tahun semester, jika memang programnya dirancang dengan tahapan satu semester. Kemudian informasi dan simpulan hasil monitoring dari proses evaluasi tersebut 
diharapkan dapat dipergunakan untuk mengambil keputusan tentang apa yang perlu dilakukan untuk membantu supaya pembelajaran kompetensi sikap spiritual berhasil sebagaimana yang telah direncanakan sebelumnya. Informasi dan simpulan hasil evaluasi diharapkan untuk mengambil keputusan tentang pembelajarannya secara utuh, mulai dari kesesuaian dengan kebutuhan masayarakat, dan tuntutan masa depan (konteks), input, proses, output, yang ditargetkan, maupum outcome yang diharapkan, dan juga untuk program-program pembelajaran berikutnya. (Muhaimin, 2011 : 374).

Implementasi penilaian kompetensi sikap spiritual harus dilakukan dalam setiap kegiatan pembelajaran di dalam kelas dan di luar kelas selama berada di lingkungan sekolah. Di dalam kelas dilakukan selama proses pembelajaran dilaksakan. Di luar kelas dilakukan saat siswa berada pada jam istirahat dan saat kegiatan ibadah shalat dhuhur dan Jumat. Alat penilaian yang digunakan berupa jurnal, lembar format observasi, format penilaian diri dan penilaian antar teman.

\section{DAYA DUKUNG KOMPETENSI SIKAP SPIRITUAL KURIKULUM 2013}

Faktor dukungan pada proses pembelajaran tergantung pada komunikasi atau hubungan antara guru dengan siswa yang serasi. Komunikasi atau hubungan tersebut bisa disebut sebagai komunikasi dua arah. Guru dapat menanyai dan mengungkap keadaan para siswa dan sebaliknya siswa dapat mengajukan berbagai persoalanpersoalan dan hambatan yang sedang dihadapi. Maka terjadilah suatu proses interaksi dan komunikasi yang humanistik. Memang guru yang menerapkan prinsipprinsip bumanistic approach akan tergolong pada bumanistic teacher. Hal ini jelas akan membantu keberhasilan studi para siswa yang bersangkutan. Berhasil dalam arti tidak sekedar tahu atau mendapatkan nilai yang baik dalam ujian, akan tetapi dapat menyentuh pada soal sikap mental dan tingkah laku atau hal-hal yang intrinsik. Dengan demikian, tujuan kemanusiaan harus selalu diperhatikan, sehingga salah satu dari hasil pendidikan yakni buman people, adalah manusia yang memiliki tingkat kesadaran untuk memperlakukan orang lain dengan penuh respect dan dignity.

Namun demikian harus diakui bahwa kegiatan yang informal semacam ini belum banyak dikembangkan. Disamping itu perlu juga diingat adanya hambatanhambatan tertentu. Misalnya kadang-kadang masih adanya sikap yang otoriter dari para guru, sikap tertutup dari guru, siswa yang pasif, jumlah siswa yang terlalu besar, sistem pendidikan, keadaan dan latar belakang guru sendiri maupun para siswanya. Hal inilah yang menjadi faktor penghambat dalam keberhasilan proses pembelajaran diantaranya mengenai kompetensi sikap spiritual pada mata pelajaran Pendidikan Agama Islam dan Budi Pekerti.

Untuk mengatasi permasaalahan di atas perlu dikembangkan sikap yang demokratis dan terbuka dari para guru serta perlu adanya keaktifan dari pihak siswa dan guru yang harus bersikap ramah dan sebaliknya siswa juga harus bersifat sopan, saling hormat menghormati, guru lebih bersifat manusiawi, rasio guru dan siswa yang lebih proporsional, masing-masing pihak bila perlu mengetahui latar belakang guru maupun siswanya. Apabila hal-hal tersebut dapat terpenuhi, maka akan terciptalah suatu komunikasi yang selaras antara guru dan siswa dalam proses pembelajaran baik di dalam kelas maupun di luar kelas. Sehingga faktor penghambat dalam proses pembelajaran akan teratasi dengan baik, dan memang untuk itu ada beberapa persyaratan yang seyogyanya perlu diperhatikan. (Ibnu Hajar, 2013 : 148)

Oleh karena itu guru perlu mengadakan komunikasi dan hubungan baik dengan siswanya. Hal ini terutama agar guru mendapatkan informasi secara lengkap mengenai diri siswa. Dengan mengetahui keadaan dan karakteristik siswa ini, maka akan sangat membantu bagi guru dan siswa dalam 
upaya menciptakan proses pembelajaran yang optimal. Maka untuk ini ada hal-hal yang perlu diperhatikan, yakni:

1. Segala bentuk kekakuan dan ketakutan harus dihilangkan dari perasaan para siswa, tetapi sebaliknya harus dapat dirangsang sedemikian rupa sehingga sifat terbuka, berani mengemukakan pendapat, dan segala masalah yang dihadapinya.

2. Semua tindakan guru terhadap siswa harus selalu mengandung kasih sayang, ibarat orang tua dengan anaknya. Guru harus bersifat sabar, ramah dan terbuka.

3. Diusahakan guru dan siswa dalam satu kebersamaan orientasi agar tidak menimbulkan suasana konflik. Sebab harus dimaklumi bahwa sekolah atau kelas merupakan kumpulan subjek-subjek yang heterogen sehingga keadaannya cukup kompleks.

Kemudian yang harus diingat oleh guru adalah dalam mengadakan sebuah komunikasi harus baik. Hubungan yang harmonis dengan siswa tidak boleh disalahgunakan. Dengan sifat yang ramah, kasih sayang dan saling keterbukaan, dapat diperoleh informasi mengenai diri siswa sebagai anak didik secara lengkap. Ini semata-mata demi kepentingan pembelajaran siswa, tidak boleh untuk kepentingan guru, apalagi untuk maksudmaksud pribadi guru itu sendiri. (Ibnu Hajar, 2013 : 153-154) Selain menciptakan komunikasi yang baik dengan siswa sebagai daya dukung dalam keberhasilan proses pembelajaran, guru juga dituntut harus dapat menciptakan suasana kehidupan sekolah yang baik. Maksudnya guru tersebut dapat menciptakan kondisi-kondisi yang optimal, sehingga anak itu merasa belajar, harus belajar, perlu dididik, dan perlu dibimbing. Usaha menciptakan kehidupan sekolah sebagaimana yang dimaksud akan menyangkut dua hal.

Pertama, yang berkaitan dengan proses pembelajaran baik di dalam kelas maupaun di luar kelas secara langsung, meliputi hal-hal sebagai berikut:

1. Pengaturan tata ruang kelas yang lebih kondusif untuk kepentingan pengajaran

2. Menciptakan iklim atau suasana belajar mengajar yang lebih serasi dan menyenangkan, misalnya pembinaan situasi keakraban di dalam kelas. Untuk menciptakan iklim yang lebih serasi ini antara lain:

a. Adanya keterikatan antara guru dengan siswa, kemudian siswa dengan siswa yang lainnya

b. Menetapkan standar tingkah laku

c. Diadakannya diskusi kelompok pada proses belajar mengajar di dalam kelas

d. Memberi penghargaan dan pemeliharaan semangat kerja

Kedua, menciptakan kehidupan sekolah dalam arti luas, yakni meliputi sekolah secara keseluruhan. Dalam hubungan ini dituntut adanya hubungan baik dan interaksi antara guru dengan guru, guru dengan siswa selaku anak didik, guru dengan pegawai, pegawai dengan anak didik. Dengan demikian memang dituntut adanya keterlibatan semua pihak di dalam lembaga pendidikan, sehingga dapat menunjang keberhasilan proses pembelajaran salah satunya mengenai kompetensi sikap spiritual yang ada pada mata pelajaran Pendidikan Agama Islam.

Selanjutnya dalam mengusahakan proses pembelajaran, guru juga harus membina hubungan baik dengan orang tua siswa. Melalui hal ini diharapkan dapat mengetahui keadaan siswa dan bagaimana kegiatan belajarnya di rumah. Juga untuk mengetahui beberapa hal tentang siswa melalui orang tuanya, sehingga dapat digunakan sebagai bahan untuk menentukan kegiatan pembelajaran yang lebih baik. Hubungan baik antara guru dengan orang tua merupakan faktor yang tidak dapat ditinggalkan, karena keberhasilan belajar siswa tidak dapat dipisahkan dengan keadaan dan usaha orang tua siswa yang 
bersangkutan. Apalagi kalau dikaitkan dengan tugas dan kewajiban seorang guru sebagai pendidik, dalam upaya membina kepribadian siswa khususnya yang ada pada kompetensi sikap spiritual, maka perlu diketahui andil orang tua sangatlah menentukan (tri pusat pendidikan) (Ibnu Hajar, 2013 : 154-155) dalam mencapai sebuah keberhasilan yang diharapkan dan telah terprogram pada administrasi yang merupakan bagaian dari perencanaan.

\section{KESIMPULAN}

Konsep atau teori yang telah diuraikan di atas mengenai "Implementasi Kompetensi Sikap Spiritual Kurikulum 2013 Pada Pembelajaran Pendidikan Agama Islam Jenjang Sekolah Menengah Atas (SMA)" merupakan sebuah teknik dan tahapan untuk mencapai keberhasilan bagi seorang guru dalam melaksanakan bimbingan terhadap siswa binaannya.

Sehingga harapannya, siswa dapat mengimplementasikan nilai-nilai yang telah diperoleh ke dalam kehidupan sehari-hari mengenai proses pembelajaran tersebut, yang telah diintegrasikan dengan kompetensi kognitif dan kompetensi psikomotor mengenai materi ajaran Islam yang wajib dipahami.

Langkah seorang guru untuk mencapai keberhasilan dan harapan tersebut, tentunya dilaksanakan melalui tahapan perencanaan pembelajaran dengan menyediakan berbagai administrasi, kemudian mengimplementasikan rencana yang telah disusun dalam administrasi tersebut ke dalam proses pembelajaran dan evaluasi pembelajaran serta guru tersebut harus dapat menganalisis daya dukung dan hambatan untuk mencapai keberhasilan dalam melaksanakan proses pembelajaran.

\section{DAFTAR PUSTAKA}

Abdul, Majid. (2012). Belajar dan Pembelajaran Pendidikan Agama Islam. Bandung: PT. Remaja Rosdakarya.

Afifuddin, ddk. (2004). Administrasi Pendidikan. Bandung: CV. Insan Mandiri.

AM, Sardiman. (2011). Interaksi \& Motivasi Belajar Mengajar. Jakarta: PT. Raja Grafindo Persada.

Anas, Salahudin. (2010). Bimbingan \& Konseling. Bandung: Pustaka Setia.

Hasan, Basri. (2009). Filsafat Pendidikan Islam. Bandung: Pustaka Setia.

Hasbiyallah. (2017). Pembelajaran Spiritual Pada Aspek Moderat. Jurnal Pendidikan Islam Universitas Islam Negeri (UIN) Sunan Kalijaga Jogjakarta. Volume 6. Hal 49.

Ibnu, Hajar. (2013.) Panduan Kurikulum Tematik. DIVA Press: Jogjakarta.

Muhaimin. (2011). Manajemen Pendidikan Aplikasi dalam Penyusunan Rencana Pengembangan Sekolah dan Madrasah. Jakarta: Kencana Prenada Media Goup.

Muzayyin, Arifin. (2012). Filsafat Pendidikan Islam. Jakarta: PT. Bumi Aksara.

Uhar, Suharsaputra. (2010). Administrasi Pendidikan. Bandung: Refika Aditama.

Yunus, Abidin. (2014). Desain Sistem Pembelajaran Dalam Konteks Kurikulum 2013. Bandung: Refika Aditama. 